\title{
KEBIJAKAN PEMERINTAH INDONESIA TERHADAP MEMBANJIRNYA PRODUK CHINA DI INDONESIA PERIODE SBY-JK
}

\author{
Elisabeth Ria Jawa, Ani Khoirunissa \\ Universitas 17 Agustus 1945 Jakarta \\ elisabethriajawa@gmail.com, aniejubaidi@gmail.com
}

\begin{abstract}
ABSTRAK
Dalam beberapa tahun terakhir ini, persaingan perekonomian antar negara-negara kawasan Asia semakin meningkat. Persaingan perekonomian ini ditandai dengan perkembangan dan laju pertumbuhan perekonomian serta permintaan pasar dan para konsumen yang meningkat. Hal ini di tandai dengan semakin banyaknya produk China yang masuk ke Indonesia. Langkah-langkah pemerintah Indonesia dalam menanggulangi membajirnya produk dari China melalui penerapan kebijakan standar nasional karena di sadari bahwa kualitas sangat penting untuk bisa unggul di pasar dunia. Kebijakan standar oleh pemerintah terhadap produk asing adalah: penerapan SM, pengawasan mutu produk, identifikasi ketersediaan SNI pada sector prioritas dan lainya. Disamping itu pula kinerja industri kecil dan menengah semakin ditingkatkan karena kekuatan ekonomi kerakyatan mempunyai peran yang penting dalam perekonomian Indonesia serta mengembangkan infrastruktur dan logistik 5ehingga pengiriman barang lebih muda dilakukan. Terdapat banyak kebijakan yang diambil oleh pemerintah untuk menangani fenomena ini namun hasilnya tidak sesuai dengan yang diharapkan masyarakat banyak kebijakan hanya menguntungkan beberapa kalangan ataupun golongan tertentu saja.
\end{abstract}

Kata Kunci : negara-negara kawasan Asia, Persaingan ekonomi, China, Indonesia

\section{PENDAHULUAN}

Indonesia dan China telah melakukan hubungan diplomatis semenjak tanggal 13 April 1950. Dari 18 April hingga 24 April 1955, Konferensi Asia-Afrika (KAA) atau Konferensi Bandung diselenggarakan di Kota Bandung, Jawa Barat, Indonesia. KAA Bandung dihadiri oleh Perdana Menteri China Zhou Enlai beserta delegasi. Dalam KAA Bandung, "Lima prinsip hidup berdampingan secara damai" yang dikemukakan pemerintah China dan disponsori bersama dengan pemerintah India dan pemerintah Myanmar mendapat dukungan dari seluruh peserta. Akan tetapi, hubungan diplomatis bilateral kedua negara tersebut sempat terhenti pada 30 Oktober tahun 1967, setelah merebaknya isu kudeta komunisme di Indonesia. Dalam periode pembekuan hubungan diplomatik, pelaksanaan perdagangan tetap dilaksanakan karena ada kesepakatan yang berbuah positif dari kamar dagang industri Indonesia dan China yang menggunakan pedoman berdasarkan kebijakan perdagangan oleh pemerintah. 
Pada Juli 1990, China dan Indonesia sepakat memperbaiki hubungan dan memulai kembali hubungan diplomatis. Dalam tahun-tahun berikutnya, pembicaraan diplomatik tingkat tinggi antara kedua negara berlanjut, menghasilkan intensifikasi hubungan ekonomi. Hubungan kedua negara lebih intensif ketika Indonesia terkena dampak krisis ekonomi tahun 1997/1998. Memasuki era reformasi, hubungan Indonesia-China setiap tahunnya semakin baik, hingga pada 2005 Hu Jin Tao dan SBY menandatangani deklasrasi hubungan kemitraan strategis. ${ }^{1}$

\section{Pasang Surut Hubungan Kerja Sama Indonesia-China}

Hubungan kerja sama bilateral antara Indonesia dengan China telah terlaksana selama enam puluh tahun. Pada masa pemerintahan Presiden Soekarno, hubungan Indonesia dengan China sangat harmonis karena Presiden Soekarno sangat anti dengan Barat. Soekarno menganggap bahwa negara Barat adalah penjajah. Sehingga Indonesia lebih condong ke arah timur. Hubungan kerja sama di antara kedua negara ini sempat mengalami penurunan dan hingga akhirnya terputus sesaat karena adanya perbedaan ideologi. China yang menganut sistem sosialis komunis dianggap sebagai pemrakarsa adanya Gerakan 30 September. Indonesia menganggap bahwa China bekerja sama dengan PKI untuk membuat politik dan pemerintahan Indonesia tidak stabil. Pada tahun 1965, Indonesia pun melakukan kudeta terhadap Gerakan 30 September. $^{2}$

Indonesia kemudian mencoba untuk memperbaiki hubungannya dengan China yang sempat terputus akibat kudeta Gerakan 30 September. Akan tetapi, proses penormalisasian tersebut tidak berjalan dengan mudah. Soeharto yang pada masa kepemimpinannya sangat anti komunisme. China berusaha memperbaiki hubungan diplomatiknya dengan Indonesia. Usaha memperbaiki hubungan kedua negara tersebut juga didorong oleh faktor internasional. Indonesia yang mempunyai peranan penting terhadap ASEAN membuat China tertarik untuk mengadakan kerja sama kembali dengan Indonesia. China yang merasa karakternya sesuai dengan hal ini, China pun memanfaatkan kesempatan baik ini. Karakter China yang kooperatif dan menghargai negara-negara ASEAN, termasuk Indonesia, membuat Soeharto berubah pikiran untuk memperbaiki hubungan diplomatik kedua negara. $^{3}$

\footnotetext{
1 . Hubungan Indonesia-Cina dalam http://www.Indonesianembassy-China.org/id/index.html.

${ }^{2}$ http://web.budaya-tionghoa.net/home/1200-pasang-surut-hubungan-indonesia-china.

${ }^{3}$ Tuty Enoch Muas, "Hubungan Indonesia -Cina Secara Historis, Dinamis!,", dalam I Wibowo dan Syamsul Hadi (eds.), Merangkul Cina (Jakarta: Penerbit PT Gramedia Pustaka Utama, 2009), hlm. 36.
} 
Penormalisasian tersebut dilanjutkan dengan adanya pembatalan syarat permintaan maaf oleh China kepada Indonesia yang semula menjadi salah satu syarat utama dalam penormalisasian hubungan tersebut oleh Soeharto. Puncak penormalisasian tersebut ditandai dengan adanya Memorandum of Understanding (MoU) yang mana sebagai nota perbaikan hubungan yang ditandatangan oleh kedua belah pihak, Indonesia diwakili oleh Presiden Soeharto dan Cina diwakili oleh Perdana Menteri Li Peng yang diumumkan secara resmi dalam kunjungan Menteri Li Peng ke Jakarta pada tanggal 8 agustus 1990. Setelah adanya kesepakatan tersebut, kedua belah pihak benar-benar mencoba untuk lebih menjaga hubungannya agar keadaan yang tidak diinginkan seperti dulu tidak terulang kembali dalam kerja sama, terutama kerja sama bilateral ini.

Agenda demi agenda secara bertahap direalisasikan kedua belah pihak dalam usaha menjalin kembali kerja sama. Agenda yang pertama kali dilakukan setelah adanya penandatanganan MoU, pada tanggal 14 November hingga 19 November 1990, Presiden Indonesia Soeharto mengunjungi China. Kemudian diikuti dengan Kunjungan Presiden China Yang Shangkun ke Indonesia pada bulan Juni 1991 serta agenda-agenda lain yang ditujukan sebagai sarana membangun kerja sama yang lebih baik lagi. Peningkatan hubungan kerja sama tersebut meningkat pada hampir semua bidang, terutama sejak berlangsungnya reformasi $1998 .^{4}$

Pada kepemimpinan Presiden B.J. Habibie, hubungan dengan China kembali membaik, namun belum begitu signifikan karena pada masa pemerintahannya masih banyak praktek-praktek diskriminasi rasial terutama pada etnis China. Sehingga hal tersebut memubuat pemerintah China merasa iba kepada warganya yang berada di Indonesia yang berdampak pada hubungan dengan Indonesia kurang berjalan dengan optimal. Berbeda dengan masa pemerintahan Presiden K.H. Abdurrahman Wahid. Pada masa pemerintahannya, Gus Dur menjadikan Imlek sebagai hari libur nasional. Dari peristiwa itulah timbul simpati terutama di kalangan etnis China. Mereka merasa dirinya dihormati. Hal tersebut juga membuat pemerintah China merasa senang dengan keputusan tersebut yang juga memperlancar kerja sama kedua belah pihak. Begitu pula di masa pemerintahan Presiden Megawati. Hubungan dengan China dirasa sangat kuat yang kemungkinan besar disebabkan faktor ayah Megawati, yaitu Soekarno yang pada masa pemerintahannya sangat dekat dengan China.

\footnotetext{
${ }^{4}$ Catatan Peristiwa Penting Dalam Hubungan Bilateral Tiongkok-Indonesia 2009/11/20, http://id.chinaembassy.org/indo/ztbd/tk/t628164.htm, diakses tanggal 2 Januari 2011.
} 


\section{KEBIJAKAN PEMERINTAH INDONESIA TERHADAP PRODUK CHINA DI INDONESIA}

Daya saing produk dan industri nasional menjadi sorotan setelah Membanjirnya produk China ke Indonesia. Mencermati kehadiran produk asal China yang masuk dalam negeri dengan harga yang sangat murah, yang membuat ancaman serius dari pelaku usaha dalam negeri. Sehingga akhirnya pasar domestik seolah menjadi "gudang" barang China. Oleh karena itu hendaknya pemerintah lebih mempertajam strategi untuk menyelamatkan pasar domestik dari hegemoni produk China, sehingga eksistensi dan performa industri lokal dapat terjamin. Sepertinya fenomena ini merupakan konsekwensi dari episode globalisasi, daripada terus mengkritik fenomena ini, lebih baik Indonesia segera berkomitmen untuk meningkatkan kompetensi, kapabilitas, dan daya saing sebagai strategi untuk dapat survive dan diperhitungkan di arena kompetisi regional maupun global. Pemerintah juga terus menyusun berbagai kebijakan yang bersifat mendorong tumbuh kembangnya usaha dalam negeri, usaha menengah, ekonomi kreatif dan membantu kemudahan permodalan. Dengan tujuan membangun industri hilir atas produk-produk kompetitif, untuk menghadapi serbuan produk China yang menguasai pasar dalam negeri. ${ }^{5}$

\section{Mencermati Arah Kebijakan Ekonomi Pemerintah SBY-JK}

Setelah lima masa pemerintahan silih berganti, pemerintah tampaknya belum mampu merumuskan kebijakan ekonomi yang sesuai dengan semangat dan kondisi riel perekonomian bangsa Indonesia. Saatnya pemerintahan yang terpilih perlu menjadikan momentum ini sebagai awal dalam menemukan dan menetapkan pijakan dasar bagi kebijakan ekonomi bangsa yang hakiki sesuai amanat UUD negara. Artinya, bahwa tanggung jawab pemerintahan dalam hal kebijakan ekonomi bukan hanya menyelesaiakan masalah target-target material ekonomi jangaka pendek, tetapi jauh dari itu adalah harus meletakan sendi-sendi moral ekonomi bangsa yang sebenarnya, yakni ekonomi bangsa yang mandiri dan merdeka. Setelah memperhatikan dan mengamati berbagai informasi yang ada dari pokok-pokok pikiran saat masa kampanye, maka secara tesirat pemerintahan ini telah berkeinginan untuk merealisasikan tujuan pokok kebijakan ekonomi tersebut. ${ }^{6}$

\footnotetext{
${ }^{5}$ http://infopublik.org/m/index.php?scr=read_news\&id=1266.

${ }^{6}$ Marsuki Dea, Analisis Perekonomian Nasional dan Internasional. (Jakarta, Mitra Wacana Media, 2005), hlm, $1 \& 2$.
} 
Pada bulan-bulan pertama pemerintahan SBY-JK, rakyat Indonesia, pelaku usaha luar dan dalam negeri maupun negara-negara donor serta lembaga-lembaga dunia, seperti IMF, Bank Dunia, dan ADB, sempat optimis bahwa kinerja ekonomi Indonesia lima tahun kedepan akan jauh lebih baik dibadingkan pada masa pemerintahan-pemerintahan sebelumnya sejak Soeharto lengser. Bahkan kabinet SBY dan lembaga-lembaga dunia tersebut menargetkan pertumbuhan ekonomi Indonesia tahun 2005 akan berkisar sediikit di atas 6\%. Banyak pihak meragukan hal tersebut, setelah kabinet Indonesia bersatu dilantik, akibat beberapa anggota kabinet yang diragukan kredibilitasnya yang tidak akan memihak pada kepentingan bangsa. Beberapa kebijakan ekonomi yang telah dirumuskan pemerintah guna merealisasikan tujuan pembangunan jangka panjang tersebut, sekurang kurangnya difokusakan pada lima prioritas kebijakan ekonomi, yakni; peningkatan peran sektor pertanian dan kehutanan, membangkitkan industri strategis, membangun infrastruktur, serta meningkatkan kegiatan perdagangan domestik dan internasional; kemudian melaksanakan kebijakan sektor energi dan sumber daya alam secaara proporsional, memperkuat ekonomi domestik dengan memanfaatkan sumber dana dalam negeri, serta mengarahkan segala potensi keuangan masyarakat dalam mengerakan perekonomian nasional dan daerah. ${ }^{7}$

Dalam tataran jangka waktu pendek dan menengah, kebijakan dibidang pertanian dan kehutanan berkaitan dengan beberapa kebijakan yang sangat bersifat protektif atau perlindungan terhadap dampak negatif praktik liberalisasi perdagangan dunia yang tidak adil, melakukan pengawasan komoditas, penetapan tarif impor, pembatasan ekspor dan perbaikan mekanisme perizinan. Kemudian dalam hubungan dengan kebijakan industri, pembenahan diantaranya akan difokuskan pada pemberdayaan badan koordinasi penanaman modal melalui inventarisasi sektor-sektor potensial yang segera dapat dikembangkan. Khusus dalam kaitannya dengan kebijakan perdagangan, kebijakan meliputi, memperluas jalur perdagangan prioritas dengan melonggarkan persyaratan impor, pemberantasan penyelundupan impor atau memperbaiki tata niaga komoditas beras dan gula. Dalam kaitannya dengan kebijakan sektor energi dan SDA, kebijakan diarahkan pada pembenahan pemanfaatan sumberdaya alam dan perbaikan subsidi BBM yang lebih tepat sasaran. ${ }^{8}$

\section{Liberalisasi Perekonomian}

\footnotetext{
${ }^{7}$ Tulus Tambunan, Perekonomian Indonesia. (Bogor, Ghalia Indonesia, 2009), hlm, 37.

${ }^{8}$ Marsuki Dea, Op Cit. hlm, 4.
} 
Di awal jalan, harapan besar terjadinya perubahan seolah sudah diciutkan dengan pemilihan tim ekonomi yang tetap saja searus dengan jalan (ekonomi) neoliberal. Jelas kiranya jalan mereka adalah wujud kesetiaan pada Konsensus Washington, yaitu deregulasi, liberalisasi, privatisasi, dan penghapusan subsidi. Pilihan jalan liberalisasi dilakukan pada hampir semua sektor vital ekonomi nasional. Misalnya saja, liberalisasi pertanian dilakukan dengan membuka kran impor beras seluas-luasnya. Akibatnya bukan saja petani lokal yang terpukul, tetapi ketergantungan pangan kepada pihak luar dan korporasi asing yang bergerak di sektor pertanian pun juga kian besar. Tidak cukup hanya itu, liberalisasi migas pun dipaksakan melalui penyerahan harga BBM pada mekanisme pasar (pengurangan subsidi), keleluasaan ekspansi korporasi migas asing, dan kenaikan harga BBM sebagai klimaksnya. Tak pelak, sektor riil mengalami kemunduran dan terparah dialami industri dan pertanian rakyat.

Liberalisasi di sektor ekonomi pun semakin dikukuhkan pada era SBY-JK dengan terbitnya UU tentang PMA No. 25 tahun 2007. Dalam UU ini ditegaskan tidak ada perbedaan antara modal asing dan modal dalam negeri. Dalam pasal 6 disebutkan bahwa "Pemerintah memberikan perlakuan yang sama kepada semua penanam modal yang berasal dari negara manapun yang melakukan kegiatan penanaman modal di Indonesia. Dalam pasal 7 ditegaskan pula bahwa "Pemerintah tidak akan melakukan tindakan nasionalisasi atau pengambilalihan hak kepemilikan penanaman modal, kecuali dengan undang-undang." Wilayah yang diperbolehkan untuk dimiliki asing pun semakin luas, dalam pasal 12 disebutkan bahwa semua bidang usaha atau jenis usaha terbuka bagi kegiatan penanaman modal, kecuali produksi senjata dan bidang usaha yang secara eksplisit dinyatakan tertutup berdasarkan undang-undang. Di fase liberalisasi yang melanda Indonesia seperti sekarang ini, orang tidak lagi berpikir tentang moralitas tapi orang akan berpikir bagaimana mewujudkan kepentingan ekonomi-politiknya, meskipun harus dengan cara mengkhianati janjinya sendiri. Rentetan kebijakan SBY-JK adalah gambaran untuk menilai arah dan kepentingan politik kaum-kaum yang pro pasar dengan corak kapitalistiknya. ${ }^{9}$

Kebijakan pemerintah SBY tidak pernah berubah, anti domestik, dan berada dipihak asing. Contohnya: UU Migas dan UU Penanaman Modal sangat kental nuansa liberalisasi. Bahkan kedua undang-undang tersebut dilahirkan dalam rangka liberalisasi ekonomi yang digencarkan oleh IMF, Bank Dunia, ADB, WTO, dan negara-negara maju. BUMN-BUMN

\footnotetext{
${ }^{9}$ http://jurnal-ekonomi.org/2009/02/07/neoliberalisme-dan-kebangkrutan-ideologi-kapitalisme/
} 
strategis diprivatisasi. Bahkan di zaman SBY-JK pemerintah memprogramkan "obral aset negara" lebih dari 40 BUMN pada tahun 2008. Pemerintahan SBY-JK merancang harga BBM Indonesia sesuai dengan harga pasar internasional. ${ }^{10}$

\section{Dampak Liberalisasi Terhadap Pertumbuhan Ekonomi Nasional.}

Ekonomi neoliberal tidak tepat untuk mengelola ekonomi Indonesia karena Kebijakan ekonomi neoliberal didasarkan pada paket kebijakan Washington Consensus yang dimaksudkan untuk menguasai perekonomian negara berkembang termasuk Indonesia. Paket kebijakan Washington Consensus meliputi: Pertama, pengurangan subsidi pemerintah kepada rakyat, sehingga menghapuskan kebijakan subsidi seperti subsidi BBM, kesehatan, pendidikan dan sebagainya. Kedua, liberalisasi sektor keuangan, industri dan perdagangan. Hal itu merupakan intervensi negara maju terhadap negara berkembang. Sebagai dampaknya adalah masuknya retail raksasa seperti Carefour dan Wall Mart ke pasaran retail Indonesia sehingga menggeser perdagangan tradisional dan membunuh usaha kecil dan mikro. Rakyat tidak mengetahui kalau tiba-tiba usaha kecilnya gulung tikar. Padahal itu disebabkan masuknya retail raksasa sebagai dampak dari kebijakan ekonomi neoliberal. Padahal Carefour dan Wall Mart di Eropa dan AS hanya boleh berlokasi di pinggiran kota, sehingga tidak mematikan usaha kecil dan mikro. Bukan di dalam kota seperti Indonesia yang akhirnya membangkrutkan pasar tradisional. Selain itu market share (bagian pasarnya) juga dibatasi. ${ }^{11}$

Kebijakan-kebijakan yang diberikan untuk mendorong bangkitnya ekonomi kapitalis, diyakini tidak akan berjalan dengan baik dan tidak akan memberikan keuntungan bagi rakyat. Ini bisa dilihat dari :

- Lemahnya daya beli masyarakat, karena harga yang tinggi dan upah yang tidak sesuai untuk mencukupi harga-harga tersebut.

- Krisis ekonomi global dimanfaatkan oleh pengusaha untuk merubah system kerja dari tetap menjadi system kerja kontrak dan outsourcing.

- Kebijakan Negara membuat program "padat karya" pada sektor manufaktur terutama perumahan tidak bisa mendongkrak perekonomian, karena daya beli yang lemah masyarakat sehingga prioritas konsumsi adalah pada kebutuhan pokok.

\footnotetext{
${ }^{10}$ Neolib di era sby oleh art of revolution dalam http:// www.facebook.com

${ }^{11}$ http://kontaktokoh.multiply.com/reviews/item/10
} 
- Program pemerintah dengan alokasi dana untuk usaha kecil menengah tidak menjawab problem besar krisis ini, karena selain ruang usaha kecil sudah cukup banyak, juga kebijakan penggusuran oleh pemda-pemda kepada PKL. Padahal PKL adalah tenaga distribusi paling handal dari sektor usaha kecil, maka potensi "konflik horizontal" akan semakin besar.

- Selain itu, salah satu contoh penerapan kebijakan neoliberal di Indonesia adalah penghapusan subsidi bagi rakyat yang dianggap sebagai pemborosan modal. ${ }^{12}$

Lesunya permintaan global akan membuat industri berbasis ekspor, seperti kerajinan, permebelan, dan tekstil, akan bangkrut. Kapasitas produksi akan menurun dan kebutuhan tenaga kerja pun berkurang. Gambaran efek krisis global yang menimpa kaum Buruh Indonesia adalah banyaknya PHK dengan alasan tidak ada order karena pasar eksport menurun sehingga perusahaan mengalami bangkrut. Selain itu, problem bahan baku yang import juga menjadi alasan untuk PHK. Gelombang besar PHK menerpa sektor industri yang banyak menyerap tenaga kerja. Sektor Industri yang akan banyak melakukan PHK adalah: Tekstile dan garment, Kuli, Perkebunan, Perkayuan. Dampak kenaikan harga BBM juga sangat panjang. Perhitungan dampak kenaikan harga BBM yang tidak jelas telah mengakibatkan pemerintah SBY lalai untuk membuat kebijakan antisipasinya. ${ }^{13}$ Akhirnya, beban rakyat terus meningkat akibat kenaikan harga-harga kebutuhan pokok.

Usaha Kecil merupakan kelompok yang paling dirugikan dengan adanya hal-hal tersebut di atas, terutama dengan adanya regulasi yang berlebihan. Usaha besar bisa menggunakan regulasi tersebut untuk ber-KKN sehingga dapat mempengaruhi kebijakan. Sementara usaha kecil tidak dapat mengakomodasikan kepentingannya, karena tidak punya kekuatan politik. Di sinilah LSM mengambil peran sebagai tim advokasi bagi kelompok usaha kecil. Usaha kecil mengandalkan pada pasar lokal, regional, nasional, dan mungkin akhirnya baru ke internasional. Artinya, bagi sebuah perusahaan kecil yang penting adalah pasar di dareah lokalnya karena itu adalah sumber permintaan. Dampak yang tidak menguntungkan dari kondisi kebjikan pemerintah adalah adanya ketergantungan ekonomi bangsa terhadap permainan pihak asing. Pelaksanaan ketentuan-ketentuan WTO sebagai instrumen liberalisasi telah menjerumuskan negara-negara berkembang yang lemah

\footnotetext{
12 http://sohib-buruh.blogspot.com/2012/05/perangkap-maut-bagi-kaum-buruh-oleh Srikat Buruh Migran Indonesia

${ }^{13}$ Dr Sri Adiningsih, “Momok PHK, Kembali Lagi?” Dalam Harian Seputar Indonesia, Rabu 4 Februari 2009.
} 
ke dalam situasi ketergantungan yang lebih intensif kepada kekuatan ekonomi pihak asing. Ketergantungan ini dimanifestasikan dalam bidang keuangan, perdagangan, dan teknologi.

Dampak dari kebijakan perdagangan yang harus ditempuh oleh pemerintah karena keterikatan dengan bantuan program IMF tersebut membuat pasar Indonesia termasuk dalam pasar yang paling terbuka, bahkan bila dibandingkan dengan negara maju sekalipun. Dalam beberapa tahun terakhir, arus masuk barang impor, khususnya barang konsumsi meningkat pesat, dan beberapa perusahaan domestik yang tidak dapat bertahan terpaksa mengurangi atau menutup usahanya. Pertanyaannya, bagaimana dampak kebijakan liberalisasi perdagangan yang makin terbuka tersebut terhadap tingkat harga industri di pasar domestik. ${ }^{14}$ Dampak liberlasisasi perdagangan akan menimbulkan persaingan antara produsen dalam negeri dengan luar negeri akan makin tajam sehingga sektor/subsektor yang tidak efisien akan keluar dari industri.

\section{Langkah-Langkah Pemerintah Dalam Menanggulangi Membanjirnya Produk China}

Suka atau tidak suka, mau atau tidak mau, pengusaha harus berhadapan dengan produk China yang dikenal murah meriah, sehingga ketidaksiapan harus diubah menjadi kesiapan. Bila selama ini pengusaha cenderung keteteran dalam menghadapi gempuran masuknya produk China, maka mulai saat ini pengusaha harus membangun kekuatan untuk menjadi pesaing tangguh produk-produk yang dihasilkan negeri Tirai Bambu. Ini memang tidak mudah. Apalagi karena Indonesia merupakan salah satu negara yang dimaraki pungutan liar (pungli), sehingga terjadi high cost pada hampir semua bidang produksi. Salah satu cara yang harus dilakukan pengusaha untuk meningkatkan daya saing adalah meningkatkan kualitas hasil produksi, menekan biaya yang tidak perlu agar lebih efisien, membuka channel distribution yang baru dengan memanfaatkan keunggulan atas pemahaman atas geogrfis dan kultur negeri sendiri. Dan yang juga penting adalah, meningkatkan kualitas SDM agar menjadi individu-individu yang memiliki semangat, motivasi, dan kualitas dalam menghadapi tantangan dan persaingan seberat apapun.

Hasil akhir dari setiap persaingan adalah perlombaan pada tingkat kualitas dan efisiensi dimana konsumenlah yang mendapatkan keuntungannya. ${ }^{15}$ Dengan penduduk berjumlah lebih dari 230 juta jiwa dan tingkat pertumbuhan ekonomi di atas $5 \%$ di saat krisis global saat ini, memang Indonesia masih menjadi primadona para pemasok dunia.

\footnotetext{
${ }^{15}$ Buletin Ekonomi Moneter dan Perbankan, Maret 2005http://www.bi.go.id/NR/rdonlyres/66FF46B37779-4828-AC7B-44BB9BFC8207/2989/cdampakliberalisasi1.pd
} 
Untuk terus dapat bersaing bukan saja dari sisi swasta yang harus mengetatkan ikat pinggang sambil meningkatkan kualitas barang dan jasanya, akan tetapi pemerintah juga sangat berkewajiban untuk mendukung terciptanya iklim usaha yang sehat dengan memangkas semua biaya ekonomi tinggi, perampingan birokrasi, kemudahan pebisnis mendapatkan kredit lunak, dan ketersediaan sumberdaya manusia yang berwawasan dan berdaya saing internasional melalui sistem pendidikan dan pelatihan di tanah air yang sungguh-sungguh dikembangkan.

Selain itu masalah penyelundupan harus diselesaikan agar daya saing produk Indonesia bisa tercapai. Pasalnya diluar penurunan tarif nol, sekarang disinyalir sinyal banyak produk ilegal yang masuk. Kalau tarifnya nol, berarti sudah tidak bisa ketahuan lagi, mana yang ilegal dan legal dengan tarif nol. Tetapi secara jangka panjang langkahlangkah tersebut tidak bisa di pertahankan. Sebagai bagian dari masyarakat dunia, bangsa ini tidak bisa mengelak dari kebijaksanaan global tersebut. Masyarakat industri harus berjuang dengan keras untuk memenangkan persaingan global yang semakin mengancam. Dibutuhkan kejelian dan kreatifitas untuk dapat menembus persaingan ketat tersebut. beberapa hal yang menjadi kelemahan barang industri China adalah kualitasnya. kelemahan ini harus di manfaatkan oleh pelaku industry di Indonesia. Investasi di daerah masih terkandala buruknya infrastruktur, terutama jalan, listrik, dan pelabuhan, retribusi serta biaya-biaya yang dipungut pemerintah daerah. Disinilah pentingnya kesadaran semua pihak untuk bahu-membahu mendorong daya saing dunia usaha dan investasi. ${ }^{16}$

\section{Penerapan Standar Nasional Bagi Produk Industri}

Dalam pasar global abad 21, pengaruh standardisasi proses dan prosedur asesmen konformitas internasional terhadap pemasaran produk dan jasa Indonesia di luar negeri akan menjadi penting. Ini memerlukan pemikiran yang serius dari pemerintah bekerja sama dengan industri dan badan standardisasi nasional dan internasional. Kelompok ini harus menjamin bahwa proses pengembangan standar dan sertifikasi mendorong, dan bukannya menjadi rintangan, pertumbuhan ekonomi Indonesia. Penting bagi suatu hubungan perdagangan global yang produktif adalah proses dan prosedur yang digunakan untuk mengembangkan dan mempublikasikan standar produk yang setara dengan tingkat standar internasional. Standarisasi produk industri memerlukan sertifikasi produk yang menyatakan bahwa produk memenuhi standar internasional terkait. Pada dasarnya prinsip yang

\footnotetext{
${ }^{16} \mathrm{http} / / / \mathrm{www}$. TablodDiplomasi. Org/current -Hubungan-Indonesia-dengan China-mengenai free-tradearea.2010.
} 
digunakan dalam Sertifikasi Produk Pengunaan Tanda SNI adalah jaminan konsistensi mutu produk yang dihasilkan oleh perusahaan harus memenuhi persyaratan SNI yang diacu. Sehingga ada 2 (dua) aspek yang harus dipenuhi oleh perusahaan untuk memperoleh sertifikat produk penggunaan tanda SNI. ${ }^{17}$ Indonesia sudah punya aturan mengenai standarisasi, yakni peraturan pemerintah (No.102/2000. Di dalam pasal 3 dinyatakan bahwa standarisasi nasional bertujuan untuk: meningkatkan perlindungan kepada konsumen, pelaku usaha, tenaga kerja, dan masyarakat lainnya, baik untuk keselamatan, keamanan, kesehatan maupun pelestarian fungsi lingkungan hidup, membantu kelancaran perdagangan dan mewujudkan persaingan usaha yang sehat dalam perdagangan. Namun dilapangan, implementasinya masih sangat lambat. Hingga Agustus 2007, pemerintah Indonesia telah menerapkan 3200 standar nasional industri, tetapi baru 215 SNI produk yang di wajibkan. SNI yang diwajibkan itu pun sebagian besar masih berlaku sukarela karena baru 34 SNI produk yang dinotifikasi ke WTO. Tanpa notifikasi tersebut, tidak ada mekanisme pengawasan dan sanksi yang diterapkan.

Disadari bahwa kualitas sangat penting untuk bisa unggul di pasar dunia, di sisi lain, Indonesia sampai saat ini masih punya masalah serius untuk memenuhi standar kualitas. Hal ini mencerminkan lemahnya pengembangan standar dan lembaga akreditasi di Indonesia. Selain karena banyaknya produk China yang masuknya tidak terkendali dan juga hambatan non tariff, termasuk masalah standarisasi. Selain standarisasi produk, standarisasi prosedur-prosedur perdagangan juga sangat penting. Standarisasi perdangan termasuk bagian penting dari fasilitas perdagangan. ${ }^{18}$

Standardisasi sebagai suatu unsur penunjang pembangunan mempunyai peran penting dalam usaha optimasi pendayagunaan sumber daya dan seluruh kegiatan pembangunan. Perangkat standardisasi termasuk juga perangkat pembinaan dan pengawasan sangat berperan dalam peningkatan perdagangan dalam negeri dan internasional, pengembangan industri nasional, serta perlindungan terhadap pemakai. Tujuan akhir kegiatan standarrisasi adalah terwujudnya jaminan mutu. Dengan demikian standarrisasi dapat digunakan sebagai alat kebijakan pemerintah untuk menata struktur ekonomi secara lebih baik dan memberikan perlindunga kepada umum. Standarisasi juga digunakan oleh Pemerintah untuk menunjang tercapainya tujuan-tujuan strategis antara lain peningkatan ekspor, peningkatan daya saing produk dalam negeri terhadap barang-barang

\footnotetext{
${ }^{17}$ Abeng Emil, “ACFTA, Antara Harapan dan Realitas,” Kompas, 18 Januari, 2010, hlm, 6.

${ }^{18}$ Tambunan Tulus., Op Cit. hlm, 268-269.
} 
import, dan peningkatan efisisensi nasional. Subsistem-subsistem atau kegiatan-kegiatan yang saling terkait satu sama lain dalam Sistem Standarrisasi Nasional terdiri dari perumusan standardisasi, penerapan standardisasi, pembinaan dan pengawasan standardisasi, kerjasama dan informasi standarisasi, metorologi dan akreditasi. ${ }^{19}$

\section{Meningkatkan Kinerja Industri Kecil, dan Menengah.}

Industri Kecil Rumahan atau UMKM harus selalu di berdayakan dan juga di kembangkan untuk membentuk suatu kekuatan ekonomi kerakyatan, yang akan membuat rakyat lebih produktif dalam berkarya untuk menunjang perekonomiannya. Banyak Sekali Produk rumahan yang tidak tersentuh pemerintah padahal potensi mereka untuk berkembang dan sukses sangatlah besar. Namun seperti halnya beberapa industri rumahan yang ada di Indonesia, kendala klasik selalu menjadi hambatan para pelaku usaha untuk bisa mengembangkan usahanya sehingga menjadi sebuah kekuatan perekonomian keluarganya, lebih jauh masyarakat disekitarnya. Kendala yang selalu menjadi hambatan para usahawan kecil rumah tangga adalah Modal, SDM, Teknologi dan Pemasaran.

Ujung tombak dari usaha apapun adalah pemasaran, hal inipun bisa dimulai dengan strategi kemitraan. Seperti halnya di Jawa Barat, Rumah Kemasan adalah salah satu cara awal untuk lebih menarik konsumen, dan harus berani dengan memanfaatkan teknologi internet untuk mempromosikan produk yang di produksinya. ${ }^{20}$ Untuk itu, dukungan aspek kelembagaan yang mengatur tugas dan fungsi pembangunan dan dukungan terhadap sektor industri rumah tangga baik secara sektoral maupun antara pusat dan daerah secara nasional akan menentukan keberhasilan pembangunan sektor industri rumah tangga yang di citacitakan. Menjadi suatu kekuatan ekonomi kerakyatan.

Tujuan program ini adalah menjadikan industri kecil dan menengah (IKM) sebagai basis industri nasional. Agar dapat menjadi basis industri nasional, IKM dituntut mampu menghasilkan barang berkualitas tinggi dengan harga yang kompetitif dan mampu menepati jadwal penyerahan secara disiplin baik untuk memenuhi kebutuhan konsumen akhir maupun untuk memenuhi pasokan bagi industri yang lebih hilir. Secara alami IKM memiliki kelemahan dalam menghadapi ketidakpastian pasar, mencapai skala ekonomi, dan memenuhi sumberdaya yang diperlukan. Sehingga untuk mencapai tujuan program ini,

\footnotetext{
${ }^{19}$ http://ipv6.postel.go.id/postelfinal/postelweb/?act=regulation\&id=5\&task=detail.

${ }^{20}$ http://id.shvoong.com/business-management/entrepreneurship/2275201-strategi-peningkatan-industri-kecilrumah/\#ixzz1ugY24HYg.
} 
pemerintah akan membantu IKM dalam mengatasi permasalahan yang muncul akibat dari kelemahan alami. ${ }^{2021}$

\section{Pengawasan Mutu Produk}

Masuknya produk-produk asal China ke pasar dalam negeri, membuat sejumlah pedagang merugi. Terkait hal itu, pemerintah akan memperhatikan hal-hal agar defisit pasar dalam negeri tidak melebar. Demikian dikatakan Menteri Koordinator Perekonomian Hatta Rajasa. Menurut Hatta, ada 3 hal yang harus diperhatikan agar defisit tidak melebar. Pertama meminta komitmen China untuk membuat balance perdagangan antara dua Kementerian Perdagangan. Kedua ada antisipasi terhadap pukulan antara pelaku industri. Hal itu dilakukan untuk menghindari terjadinya collaps pada industri dalam negeri. Dan ketiga Pemerintah Indonesia akan tetap menghormati ASEAN untuk menjaga balance of trade antara kedua negara. Setelah penerapan ACFTA, persoalan tentang daya saing produk dan industri nasional menjadi sorotan. Membanjirnya produk China ke Indonesia telah membuat banyak kalangan meminta pengambil kebijakan mengambil langkah untuk menata industri, debirokratisasi dan mengurangi high-cost economy.

Pemerintah juga telah memiliki sejumlah program untuk percepatan pembangunan infrastruktur dan konektivitas untuk memperlancar jaringan produksi nasional. Implementasi dari program-program tersebut akan sangat membantu bagi penciptaan daya saing produk dan industri Indonesia. Sistem industri Indonesia tidak memiliki kemampuan responsif dan adaptif yang mandiri. Karenanya sangat lemah dalam mengantisipasi perubahan dan tak mampu melakukan tindakan-tindakan preventif untuk menghadapi terjadinya perubahan tersebut. ${ }^{22}$ Tuntutan perubahan pasar dan persaingan antar industri secara global tidak hanya mencakup perubahan di dalam corak, sifat, kualitas, dan harga dari komoditas yang diperdagangkan, tetapi juga tuntutan lain yang muncul karena berkembangnya idealisme masyarakat.

Pengawasan mutu secara wajib untuk produk industri dalam negeri telah dilaksanakan melalui sertifikasi produk penggunaan tanda SNI, sedangkan pengawasan mutu secara wajib untuk beberapa produk industri bertujuan ekspor telah dilaksanakan melalui sertifikasi produk penggunaan tanda SNI atau sertifikasi mutu produk. Dalam rangka memberikan perlindungan terhadap masyarakat dan kesiapan menghadapi

\footnotetext{
${ }^{21}$ http://id.shvoong.com/business-management/business-ideas-and-opportunities/2199801-industri-rumahtangga/\#ixzz1ugamQsI4

${ }^{22}$ Metrotvnews.com, Jakarta., Pemerintah Siapkan Penanganan Membanjirnya Produk China.
} 
globalisasi perdagangan maka diperlukan adanya perangkat hukum nasional di bidang pengawasan mutu produk impor dan pengawasan mutu produk yang beredar di pasar dalam negeri. ${ }^{23}$ Dalam rangka meningkatkan mutu dan daya saing hasil produksi, usaha industri kecil dibantu dengan upaya pengendalian dan manajemen mutu. Bimbingannya diberikan melalui kelompok Gugus Kendali Mutu (GKM) pada unit usaha mereka. Upaya ini terus ditingkatan agar kesadaran akan perlunya penerapan manajemen mutu membudaya dan menjadi bagian integral dalam kegiatan produksi. Untuk mendukung industri kecil yang mempunyai potensi ekspor agar mampu menerobos pasar internasional, pemasyarakatan dan bimbingan penerapan sistem manajemen mutu ISO-9000 (International Standards Organization 9000 series) makin diperluas. ${ }^{24}$

Ada hubungan erat antara mutu suatu produk dengan kepuasan pelanggan serta keuntungan industri. Mutu yang lebih tinggi menghasilkan kepuasan pelanggan yang lebih tinggi, sekaligus mendukung harga yang lebih tinggi dan sering juga biaya lebih rendah. Eksekutif puncak masa kini melihat tugas meningkatkan dan mengendalikan mutu produk sebagai prioritas utama, sehingga setiap industri tidak punya pilihan lain kecuali menjalankan manajemen mutu total ("Total Quality Management"). Manajemen mutu total dapat dilihat sebagai pendekatan utama untuk mendapatkan kepuasan pelanggan dan keuntungan industri. Industri harus memahami bagaimana pelanggannya memandang mutu dan tingkat mutu yang diharapkan pelanggan. Industri harus berusaha menawarkan mutu lebih baik dari pada saingannya. Hal ini melibatkan komitmen manajemen dan karyawan secara total dalam usaha mencapai mutu yang lebih tinggi. Salah satu upaya dalam meningkatan daya saing komoditi Indonesia di pasar-pasar dunia, pada taraf pertama dilakukan penyeragaman mutu, yang dilanjutkan dengan pembakuan mutu atau standrisasi dan kemudian secara selektif diadakan standarisasi mutu khusus. Sebagaimana diketahui, sejak akhir tahun 1960-an pemerintah secara intensif telah melakukan penyeragaman dan pembakuan mutu komoditi Indonesia secara sektoral yang dilakukan oleh masing-masing departemen teknis. ${ }^{25}$

\section{Pengembangan Infrastruktur dan Logistik}

Laporan tahunan dari WEF menunjukan bahwa Indonesia selalu ada di peringkat rendah. Padahal, salah satu penentu utama keberhasilan suatu negara untuk dapat bersaing

\footnotetext{
${ }^{23} \mathrm{http}$ ://lingkarmutuindonesia.blogspot.com/2012/03/kebijaksanaan-pemerintah-dalam.html.

${ }^{24} \mathrm{http}: / /$ permanas.wordpress.com/2008/03/05/strategi-pemasaran-dan-pengendalian-mutu-produk.

${ }^{25}$ M.S. Amir. Seluk-Beluk dan Teknik Perdagangan Luar Negeri( Jakarta: PT Pustaka Binaman Presindo 1991), hlm, 217.
} 
di dalam era globalisasi dan perdagangan bebas adalah jumlah infrastuktur yang mencukupi dengan kualitas yang baik. Buruknya infrastruktur dengan sendirirnya meningkatkan biaya produksi yang pada akhirnya menurunkan daya saing harga dengan konsekuansi ekspor menurun. Tantangan yang dihadapi Indonesia saat ini dalam infrastruktur adalah sebagai berikut: 1) memperbaiki semua infrastruktur yang sudah rusak, seperti jalan-jalan raya yang sudah berlubang dan bergelombang yang sebagian hancur karena tanah longsor dalam waktu singkat. 2) membangun jalan tol atau jalan kereta api ke pelabuhan, dan memperluas kapasitas dan memperbaiki manajemen pelabuhan, seperti Tanjung Priok dan lainnya, yang selama ini menjadi pintu keluar masuk barang dalam beberapa tahun kedepan. 3) meningkatkan akselerasi listrik dalam waktu dekat dan lainya.

Logistik merupakan bagian terpenting dari infrastruktur dalam kaitannya dengan kepentingan ekonomi atau urat nadi perdagangan pada khususnya. Tanpa kelancaran logistik, proses produksi dan perdagangan dapat terganggu. ${ }^{26}$ Biaya logistik yang tinggi dan buruknya infrastruktur dinilai merupakan kendala yang menghambat pertumbuhan industri dalam negeri. Untuk itu, pemerintah perlu merangsang investasi dengan serius menggarap infrastruktur dan transportasi. Dengan sumber daya alam yang tersebar, investor yang tertarik menanamkan modal di pelosok Indonesia selalu memperhitungkan ketersediaan infrastruktur seperti listrik, pelabuhan dan jalan raya. Untuk mendukung logistik dan distribusi produk, harus ada jalur transportasi memadai. Hingga saat ini, infrastruktur serta sarana prasarana transportasi yang ada masih sangat minim. Pelaku usaha harus mengeluarkan biaya tiga kali lipat dalam memasarkan produknya.

Besarnya biaya logistik membuat produk dalam negeri tidak mampu bersaing dengan produk impor, terutama asal China. Mahalnya proses distribusi membuat harga produk Indonesia jauh lebih mahal dibandingkan produk China. Pasalnya, teknologi China sendiri jauh lebih maju, dan ekspansi pasar produknya juga cukup besar. selain biaya distribusi yang tinggi, pungutan liar (pungli) di setiap daerah membuat pelaku usaha harus mengeluarkan biaya ekstra. Pungutan liar (pungli) pada setiap daerah merupakan daftar biaya yang perlu dikeluarkan di samping biaya logistik. Hal tersebut membuat harga produk di setiap kota berbeda. ${ }^{27}$

\section{Solusi Baru Ekonomi Indonesia, Mengembangkan Industri Kreatif}

\footnotetext{
${ }^{26}$ Tambunan Tulus., Op Cit. hlm, 278 .

${ }^{27} \mathrm{http}$ ://eportofolio.com/market-news/biaya-logistik-dan-infrastruktur-hambat-pertumbuhan-industri.html.
} 
Kemunculan industri kretaif memiliki kaitan yang erat dengan globalisasi. Globalisasi dan kemajuan teknologi telah menciptakan interkoneksi antarmanusia sedemikian rupa, sehingga merubah karakter, gaya hidup, dan perilaku masyarakat menjadi lebih kritis dan peka. Selera masyarakat akan barang dan jasa yang diproduksi dan dikonsumsinya pun mengalami perubahan. Dan perubahan ini berlangsung dengan cepat dan semakin bertambah cepat dari hari ke hari. Perubahan yang berlangsung cepat menuntut manusia merespon dengan cepat supaya tidak ketinggalan. Disinilah perananan kreatifitas dan inovasi sangat diperlukan. Manusia-manusia yang kreatif dan inovatif akan mersepon perubahan dengan cepat dan kemudian menyesuaikan diri dengan cepat pula, sehingga ia mendapatkan keuntungan karenanya. Lebih jauh lagi, perubahan selera masyarakat membuat barang atau jasa yang dikonsumsi bukan lagi hanya di pandang dari fungsi primernya saja, tetapi ada tuntutan akan nilai-nilai tambah tertentu yang menjadikan sebuah barang atau jasa memiliki keunikan. Keunikan yang memunculkan nilai tambah ini membutuhkan kreatifitas dan inovasi dari para pembuatnya. Keunikan-keunikan yang terkandung pada barang atau jasa inilah yang bisa diberi identitas produk industri kreatif. ${ }^{28}$

Istilah ekonomi kreatif dan industri kretaif mulai marak diperbincangkan di Indonesia sejak tahun 2006. Kedua istilah tersebut sebenarnya saling terkait, dimana industri kretaif merupakan jantung dari ekonomi kreatif. Ekonomi kreatif adalah kegiatan ekonomi dimana input dan output utamanya adalah gagasan. Gagasan merupakan esensi utama dari kreatifitas. Gagasan dapat menciptakan sebuah produk dan jasa yang memiliki nilai ekonomi tinggi sehingga bisa mempengaruhi perekonomian agregat suatu negara. Di Indonesia, selama periode 2002-2006 industri kreatif menempati urutan ke-7 dari 10 sektor lapangan usaha yang memberikan kontribusi besar terhadap PDB, yakni sebesar 6,28\%. Pada periode yang sama, industri kreatif mampu menyerap tenaga kerja sebanyak 5,4 juta orang dengan tingkat partisipasi sebesar 5,8\%, serta bisa mengurangi angka kemiskinan dan memberdayakan UKM meskipun belum ada angka yang pasti. Produktifitas di industri kreatif mencapai 19,5 juta pekerja pertahun, melebihi produktivitas nasional yang kurang dari 18 juta pekerja pertahun.

Industri kreatif bisa dikembangkan oleh negara manapun, baik negara maju maupun berkembang karena setiap negara pasti memiliki sumber daya-sumber daya kreatif yang tak terbatas seperti: manusia-manusia yang kretaif, kebudayaan yang bisa di eksplorasi, dan

\footnotetext{
${ }^{28}$ Suhodo Diah Setiari, "Industri Kreatif, Solusi Baru Ekonomi Indonesia," Jurnal Ekonomi Pembangunan, VOL.XVII(2), 2009. LIPI.
} 
sebagainya. Perdagangan dunia untuk industri kreatif masih didominasi negara-negara maju meski ada beberapa negara berkembang yang ikut menikmati boom industri kreatif, khususnya negara-negara di Asia. Meskipun demikian, negara berkembang pun sangat bisa untuk meningkatkan industri kreatifnya karena sumber daya kreatif banyak berada di negara berkembang. Tentu saja selama negara berkembang bisa mengatasi kendala-kendala yang menghalangi berkembangnya industri kreatif. Strategi-strategi pengembangan yang tepat, koordinasi diantara instansi-instansi terkait dengan industri kreatif dan kerjasama pemerintah, cendekiawan dan dunia bisnis sangat diperlukan untuk mengoptimalkan pengembangan industri kreatif. $^{29}$

\section{Karaktersitik Industri Kreatif}

Kreativitas meliputi tiga hal, pertama kreativitas merupakan kemampuan untuk membayangkan atau menemukan suatu hal yang baru, kedua kreativitas merupakan sikap untuk menerima perubahan dan sesutau yang baru, ketiga kreativitas merupakan suatu proses dimana individu kreatif merupakan individu yang secara kontinu terus belajar dan melakukan perbaikan perbaikan-perbaikan secara bertahan pada pekerjaan kreatifnya. Industri kreatif merupakan industri yang memproduksi tangible dan intangible output yang memiliki nilai ekonomi melalui eksplorasi nilai-nilai budaya dan produksi barang dan jasa berbasiskan ilmu pengetahuan, baik produk tradisional maupun modern. Nilai ekonomi dari produk atau jasa kreatif tidak lagi ditentukan oleh bahan baku atau sistem produski saja dan tidak lagi dapat bersaing hanya dengan mengandalkan harga atau mutu produk tetapi ditentukan oleh kreativitas, inovasi dan imajinasi. Industri kreatif merupakan pilar utama dalam pembentukan ekonomi kreatif. ${ }^{30}$

Karakteristik ekonomi kreatif antara lain: 1) memiliki potensi untuk dikomersialkan, sehingga berpengaruh pada pertumbuhan dan pembangunan ekonomi. 2) dapat mendorong penciptaan sumber pendapatan baru, membuka peluang kerja baru dan peluang ekspor sambil mempromosikan keberagaman budaya dan pembangunan manusia.

3) merupakan aktivitas ekonomi berbasis ilmu pengetahuan yang memiliki dimensi pembangunan dan lintas hubungan pada level makro dan mikro ekonomi. 4) menyatukan aspek ekonomi, budaya, dan sosial dalam erinteraksi dengan teknologi, kekayaan intelektual dan obyek pariwisata. Dalam implementasinya di seluruh dunia dewasa ini, industri kreatif telah memunculkan kota-kota kreatif sebagai basis produksinya. Istilah kota

\footnotetext{
${ }^{29} \mathrm{http} / / / \mathrm{www}$. seputar-indonesia.com/edisicetak/content/view/480750.

${ }^{30}$ Sumber: http://www.pascaunhas.net/jurnal_pdf/analisis-eko-pemb/sultan-6.pdf.
} 
kreaatif diberikan kepada kota yang telah memiliki berbagai aktivitas kultural yang telah menyatu dengan aktivitas ekonomi dan sosial kota tersebut. Kota-kota kreatif ini cendedrung dibangun diatas fondasi infrastruktur sosial dan kultural yang kuat, memiliki jumlah manusia kreatif yang relatif banyak, dan menarik minat investor karena memiliki karakter yang kuat dan fasilitas budaya yang lengkap. ${ }^{31}$

\section{Alasan Mengembangkan Industri Kreatif}

selain memiliki dampak signifikan secara ekoonomi utamanya dari perdagangan, baik nasional dan internasional dari produk barang dan jasa kreatif. Pengembangan industri kreatif juga memiliki dampak positif terhadap aspek-aspek lainnya, seperti aspek sosial, budaya, lingkungan, serta citra indentitas bangsa. Industri kreatif juga bisa menciptakan iklim bisnis yang positif, mendukung pemanfaatan sumber daya yang terbarukan, dan mendorong penciptaan inovasi-inovasi baru.

\section{Aspek Ekonomi}

Dari perspektif ekonomi, berkembangnya perdagangan internasional adalah dampak langsung dari ekonomi kreatif. Selama periode 2000-2005, perdagangan internasional barang dan jasa di industri ini tumbuh rata-rata 8,7\% per tahun. Di negara-negara maju, kontribusi industri kreatif terhadap PDB negara menunjukan peningkatan yang berarti dari tahun ketahun. Di Inggris, industri kreatif menyumbang 8,2\% dari PDB negara, dan di Indonesia sendiri industri kreatif memiliki kontribusi terhadap PDB nasional sebesar ratarata $6,3 \%$ per tahunnya. Potensi pasar industri kretaif sangatlah besar, hampir $50 \%$ belanja masyarakat di negara-negara maju merupakan produk dan jasa kreatif. Hal ini menjadi peluang bagi indonesia karena negara-negara maju tersebut merupakan negara-negara utama tujuan ekspor Indonesia. Pangsa pasar produk dan jasa kreatif di berbagai negara pun terus mengalami peningkatan dari tahun ketahun. Hal ini membuka peluang bagi produk dan jasa kreatif Indonesia untuk mencari dan membuka pasar-pasar baru di negaranegara lain di luar negara utama tujuan ekspor konvensial.

\section{Aspek Sosial}

Dampak sosial yang utama dari industri kreatif adalah kontribusinya pada penciptaan lapangan kerja. Industri kreatif menciptakan banyak lapangan kerja dan profesi-profesi baru yang menjanjikan dari segi pendapatan dimana profesi-profesi ini sebelumnya tidak ada atau tidak dianggap. Peranan industri kreatif pada penyerapan tenaga kerja biasanya

\footnotetext{
${ }^{31}$ Suhodo Diah Setiari., Op Cit. hlm, 19.
} 
cukup signifikan, sekitar 2-8\% dari keseluruhan tenaga kerja. Di Indonesia, industri kreatif rata0rata mampu menyerap tenaga kerja sekitar 5,4 juta jiwa pertahun. Industri kreatif juga memiliki peranan penting untuk mengikat manusia-manusia pelaku industri kreatif ke dalam kerjasama sosial. Lebih jauh lagi, industri kreatif bisa menjadi tempat aktualisasi diri individu-individu kreatif, yang selain bisa menjadi penyalur gagasan-gagasan kreatif bernilai ekonomi tinggi juga memiliki peluang untuk berkompetisi dan mendapatkan penghargaan baik di tingkat nasional maupun internasional.

3. Aspek Kebudayaan

Industri kreatif memiliki hubungan yang sangat erat dengan kebudayaan, karena beberapa subsektor dalam industri kreatif adalah subsektor yang memiliki konten budaya, seperti kerajinan, pasar barang seni, seni pertunjukan dan lainnya. Adanya industri kreatif berarti produk-produk budaya bisa lebih dikembagkan, tentunya dengan kreasi dan inovasi, sehingga produk budaya yang selama ini memiliki kesan "membosankan" dan "kuno" dapat dikemas dengan lebih atraktif dan menarik serta tentunya memiliki nilai ekonomi yang tinggi. Pengemasan produk-produk budaya menjadi suatu yang menarik tentu saja akan berdampak positif bagi pelestarian budaya bangsa. Lebih jauh lagi, pemasaran produk-produk budaya dengan sentuhan kreatif ke luar negeri akan bisa mengenalkan Indonesia di mata dunia. Pengembangan prpduk-produk budaya sebagai komoditas industri kreatif juga akan mengembangkan sektor pariwisata Indonesia. Pengemasan produk budaya yang modern di sertai inovasi-inovasi baru tentunya akan menarik domestik maupun mancanegara. Pada akhirnya, hal ini akan memberikan dampak ekonomi yang luar biasa bagi Indonesia. ${ }^{32}$

\section{Kesimpulan}

Berdasarkan hasil penelitian maka penulis menyimppulkan bahwa Membanjirnya produk-produk dari China khususnya untuk kelompok produk permesinan, kelompok elektrik dan kelompok besi dan baja berpotensi menyaingi keberadaan industri lokal. Hal ini disebabkan impor produk tersebut meningkat secara signifikan, nilai impornya paling tinggi diantara produk impor China lainnya. Serbuan produk impor China berpotensi mengancam eksistensi produk usaha mikro, kecil dan menengah (UMKM) di pasaran. Seperti diketahui, produk impor China banyak memiliki keunggulan dibanding produk UMKM, namun kualitasnya tidak jauh berbeda dengan produk nasional. Selain harganya

\footnotetext{
${ }^{32}$ Departemen perdagangan, pengembangan ekonomi kreatif 2025. 2008.
} 
lebih murah, produk impor China memiliki banyak varian dan model yang menarik. Yang lebih mengkhawatirkan adalah penyebab membanjirnya produk China di Indonesia juga disebabkan karena banyaknya barang-banrang selundupan atau impor illegal, dan banyaknya pintu masuk jalur perdagangan yang tidak mendapat pengawasan yang ketat dari pemerintah.

Dampak dari membanjirnya produk China sangat mengkhawatirkan produsen dan produk dalam negeri baik modern maupun tradisional karena meresahkan banyak pedagang, pekerja dan pengusaha serta menyebabkan industri tekstil dan produsen garmen nasional mati satu persatu. Banyak industri dan perusahaan yang tidak siap dengan adanya ancaman terhadap bisnis mereka juga akan menambah daya saing produksi yang semakin melemah.

Terdapat banyak kebijakan yang di ambil oleh pemerintah dalam menangani perekonomian dalam negeri khusunya dalam menghadapi serbuan produk China yang membanjiri pasar di seluruh daerah di Indonesia. Namun banyak kebijakan yang belum terealisasikan dengan baik. kebijakan yang dibuat oleh pemerinyah tidak tepat pada sasarannya, sehinga masyarakat selalu mengalami kesulitan dalam membangun dan menjalankan usahanya. Banyak kebijakan pemerintah yang tidak memihak kepada kepentingan dan kesejahteraan masarakat di negerinya sendiri tetapi lebih memihak pada kepentingan golongan atau kelopmok tertentu, yang juga memberi keuntungan untuk para pembuat kebijakan.

Pembenahan besar-besaran memang diperlukan agar dampak buruk dapat dihindari. Dimulai dari struktur atas, para pengambil kebijakan dan birokrat. Para birokrat harus mampu menciptakan kebijakan-kebijakan dan regulasi yang kreatif, yang mendukung dan memberi kemudahan bagi para pengusaha dalam menjalankan usahanya, juga peningkatan produktivitas. Dimasyarakat, edukasi tentang penghargaan terhadap produk-produk dalam negeri harus diberikan sejak dini, agar masyarakat tidak hanya menjadi alat pendukung pengembangan hegemoni ekonomi China di Indonesia.

\section{DAFTAR PUSTAKA}

\section{Buku :}

AK. Syamin, S.H.,MH. 1998. Hukum Diplomatik : Suatu Pengantar. Bandung. Armico.

Asrudin \& Mirza J. Kusuma. 2009. Refleksi TeoriHubungan Internasional dari Tradsional ke Kontemporer. Yogyakarta. Graha Ilmu.

Badri, Jusuf. 1994. Kiat Diplomasi. Jakarta. Pustaka Sinar Harapan Boediono. 2009. Ekonomi Indonesia Mau kemana?. Jakarta.Gramedia. 
Banyu perwita DR. Anak Agung dan DR. yayan Mochamad Yani. 2005. Pengantar Ilmu Hubungan Internasional. Bandung. PT. Remaja Rosdakarya.

Culla, Adi Suryadi. 2006.Rekonstruksi Civil Societty: Wacana dan Aksi Ornop di Indonesia. Jakarta: LP3ES.

David, Blaam \& Veseth Michael. 1996. Introduction to International Political Ekonomy. New Jersey. Prentice.

Deliarnov,M.Sc. 2006. Ekonomi Politik Internasional. Jakarta. Erlangga

Djiwandono, J. Soedrajad. 1992. Perdagangan dan Pembangunan: Tantangan, Peluang dan

Kebijaksanaan Perdagangan Luar Negeri Indonesia. Jakarta. LP3ES.

Frangkel, J. 1980. Hubungan Internasional. Jakarta. Sungguh Bersaudara.

Greenspan, Alan. 2008. Abad Prahara: Ramalan Kehancuran Ekonomi Dunia Abad Ke-21. Jakarta. PT Gramedia Pustaka Utama

Hamzah, Fahri. 2010. Negara Pasar dan Rakyat: Pencarian Makna dan Relevansi. Jakarta. Faham Indonesia.

Jackson, Robert \& Georg Sorensen. 1999. Pengantar Study Hubungan Internasional. yogyakarta. Pustaka Pelajar.

John \& Doris Nasibit. 2010. China's Megatrends. Jakarta. PT.Gramedia

Kartodirdjo, Sartono. 1987. Kebudayaan Pembangunan Dalam Perpektif Sejarah. Yogyakarta, Gadjah Mada University press.

Kusuma, Wijaya. 2008. China Mencari Minyak : Diplomasi China Ke Seluruh Dunia 1990 2007.Jakarta. CCS

Keane, John. 1988. Democracy and civil Society. London

Liji, Liang. 2012. Dari Relasi Upeti Ke Mitra Strategis: 2.000 Tahun Perjalanan Hubungan

Tiongkok-Indonesia. Jakarta. PT. Kompas Media Nusantara.

Mas'oed, Muchtar. 1994. Ilmu Hubungan Internasional: Disiplin dan Metodologi. Jakarta. LP3ES

Mas'oed,M uchtar \& Colin Mac Andrews. 2006. Perbandingan Sistem Politik. Yogyakarta. Gajah

Madah University Press.

Morgenthau, Hans. 1990. Politik Antar Bangsa. Jakarta. Yayasan Obor Indonesia.

Nawiyanto. 2010. Mata Hari Terbit dan Tirai Bambu: Persaingan Dagang Jepang dan China. Yogyakarta. Penerbit Ombak.

Rudy, Drs. T. May, SH.,MIR., M.Sc. 2005. Adminstrasi dan Organisasi Internasional. Bandung.

PT. Rafika Aditama.

Schuman, Gary \& Clara Joewono. 1990. Hubungan Indonesia-Amerika Serikat: Sebuah Laporan.Jakarta. CSIS

Shenker, Oded. 2007. The Chinese Cebtury: Bangkitnya Raksasa China dan Dampaknya Terhadap Perekonomian Global. Jakrata. PT Bhuana Ilmu Populer.

Soeprapto,R. 1997. Hubungan Internasional: Sistem, Interaksi, dan Perilaku. Jakarta. PT. Raja Grafindo Persada.

Soetomo. 2009. Pembangunan Masyarakat: Merangkai Sebuah Kerangka. Yogyakarta. Putaka Pelajar.

Suhartao, Edi. 2007. Kebijakan Sosial Sebagai Kebijakan Publik: Peran Pembangunan

Kesejahteraan Sosial dan Pekerjaan Sosial Dalam Mewujudkan Negara Kesejahteraan di Indonesia. Bandung. Alfabeta

Suryadinata, Leo. 1998. Politik Luar Negeri Indonesia Di Bawah Soeharto. Jakarta. LP3ES

Tambunan, T.H., Tulus. 2009. Perekonomian Indonesia. Jakarta. Ghalia Indonesia 
Wibowo,I \& Syamsul Hadi. 2009. Merangkul China: Hubungan Indonesia China pasca Soeharto. Jakarta. PT. Gramedia Pustaka Utama.

Winarno, Budi. 2008. Globalisasi : Peluang atau Ancaman Bagi Indonesia. Jakarta. Erlangga Wuryandari, Ganewati dkk. 2008. Politik Luaar Negeri Indonesia : Ditengah Pusaran Politik Domestik. Jakarta. Pustaka Pelajar

Xiang Jun, Dr. Wang, Ph.d. 2010. China Membeli Dunia. Yogyakarta. Pustaka Solomon. Yunanzi, Kong. 1999. Silang Budaya China-Indonesia. Jakarta. Ilmu Bhuana Populer. Zeng Ming \& Peter J Wiliamson. 2008. Ancaman Sang naga: Strategi China Menggempur Dominasi Pesaing Mapan di Pasar Global. Jakarta. Gramedia Pustaka Utama.

\section{B. Referensi Lainya}

1. Tabloid Diplomasi tahun 2009 dan 2010

2. Jurnal Ekonomi dan Pembangunan. Vol.XVII (2) 2009

3. Kompas 2010 dan 2011 http://www.antara.co.id. http://www.wordpress.com. http://politik.kompasiana.com/2010/10/02 http://www.bataviase.co.id http://www. Indonesian-Embasy-China.org/id/index.html http://www.jurnas.com http://www.diplomacy.blogspot.com/2010/06/.html http://www.kemhan.go.id/buku_putih.pdf http://www.deplu.go.id/pages.aspx? http://www.kapanlagi.com/ekonomi/internasional http://www.bps.go.id/brs_file/pdb -21nov05.pdf http://www.ekonomy.okezone.com http://www.nusantaranews.wordpress.com http://www.lingkarmutuindonesia.blogspot.com/html http://www.seputar-indonesia.com/edisicetak/content/view/480750/ http://www.pascaunhas.net/jurnal_pdf/analisis-eko-pemb/sultan-6.pdf 
